\title{
Editorial
}

\section{Gennady A. Buznikov, PhD (1931-2012): Father of Neurotransmitters as Developmental Signals}

\author{
Yuri B. Shmukler ${ }^{\mathrm{a}}$ Jean M. Lauder ${ }^{\mathrm{b}}$ \\ ${ }^{a}$ Koltzov Institute of Developmental Biology, Russian Academy of Sciences, Group of Embryophysiology, Moscow, \\ Russian Federation; ${ }^{\mathrm{b}}$ Department of Cell Biology and Physiology, University NC School of Medicine, \\ Chapel Hill, N.C., USA
}

Gennady Buznikov died on August 27, 2012, in Los Angeles, Calif., USA, where he lived with his wife Lyuda Nikitina, after a brief illness (fig. 1).

He was born on January 18, 1931, in Leningrad (Saint Petersburg), Russia. His early childhood left a lasting impression. Before World War II, his father was subjected to political repression and imprisoned. When Gennady was only 10, he was evacuated from Leningrad just before the city was sieged by the Germans in 1941, and placed in a children's home. Despite this, Gennady had the strength of character and natural abilities to pass the entrance exam for admission to the Biology Faculty of the M.V. Lomonosov Moscow State University, where he pursued his graduate studies.

The post-war wave of political repressions caused his mother to lose her job and be blacklisted. This left the family penniless, except for a small scholarship and parttime work of Gennady. Life obstacles were balanced to some extent by success in scientific research in the Department of Human and Animal Physiology at Moscow State University, carried out under the direction of Prof. Khachatur Koshtoyantz. This research on the role of hyaluronidases in the hatching of bony fish began as a student research project and became the basis of his $\mathrm{PhD}$
Gennady A. Buznikov

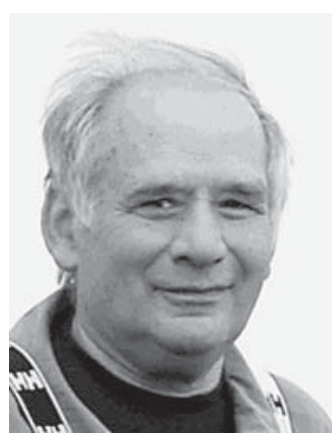

thesis, which he successfully defended in 1956. However, this work did not become the main direction of Gennady's research.

The events that determined the direction of his research career occurred at the end of the 1950s, when he, together with his colleague Boris Manukhin, followed up on the proposal by Koshtoyantz that chemical mechanisms of the nervous system are derived from the prenervous system of regulation in early development. In 1961, they published the first evidence that 5-hydroxytryptamine $(5-\mathrm{HT})$ regulated embryogenesis in a marine mol-

\section{KARGER}

E-Mail karger@karger.com

www.karger.com/dne
(C) 2013 S. Karger AG, Basel

0378-5866/13/0355-0359\$38.00/0
Jean M. Lauder

Deparment of Cell Biology and Physiology

University NC School of Medicine

Chapel Hill, NC 27599-7090 (USA)

E-Mail unclau@med.unc.ed 
lusc $[1,2]$. This led the way for the establishment of a new role for neurotransmitters, like 5-HT, as 'developmental signals' during embryogenesis. In 1966, he defended a dissertation on this topic for his Doctor of Biological Sciences degree.

Buznikov's body of work on marine organisms, primarily sea urchins, provided convincing evidence that 5 -HT is a critical regulator of developmental events, like the cell cycle, blastomere interactions and morphogenesis in early embryos [3-11].

The list of Buznikov's ideas is completed by the concept of intracellular localization of embryonic neurotransmitter receptors, first proposed in his monograph
Neurotransmitters in Embryogenesis [12], which remains the most exhaustive source on this topic in the field. At the end of his scientific career, Buznikov hypothesized that neurotransmitter conjugates with functionalized fatty acids can exist as endogenous regulators of embryonic development [13]. Students who obtained their $\mathrm{PhD}$ degrees under his mentorship, colleagues in the Group of Embryophysiology at the N.K. Kolztov Institute of Developmental Biology, and a number of scientists around the world are continuing work in the field of embryonic neurotransmitter functions established by Gennady Buznikov.

\section{References}

1 Buznikov GA, Manukhin BN: A serotoninlike substance in the embryogenesis of certain gastropodal molluscs. Zh Obshch Biol 1961; $22: 226-232$.

- 2 Koshtoyants KS, Buznikov GA, Manukhin $\mathrm{BN}$ : The possible role of 5-hydroxytryptamine in the motor activity of embryos of some marine gastropods. Comp Biochem Physiol 1961;3:20-26.

3 Buznikov GA, et al: Changes in serotonin content in cleaving sea urchin eggs (fluorometric and histochemical determination). Sov J Dev Biol 1972;3:257-260.

4 Buznikov GA, Shmukler Y: Possible role of 'prenervous' neurotransmitters in cellular interactions of early embryogenesis: a hypothesis. Neurochem Res 1981;6:55-68.
Buznikov GA: The action of neurotransmitters and related substances on early embryogenesis. Pharmacol Ther 1984;25:23-59.

-6 Buznikov GA, et al: The pre-nervous serotonergic system of developing sea urchin embryos and larvae: pharmacologic and immunocytochemical evidence. Neurochem Res 2005;30:825-837.

7 Buznikov GA, Lambert HW, Lauder JM: Serotonin and serotonin-like substances as regulators of early embryogenesis and morphogenesis. Cell Tissue Res 2001;305:177-186.

8 Buznikov GA, Chudakova IV, Zvezdina ND: The role of neurohumours in early embryogenesis. 1. Serotonin content of developing embryos of sea urchin and loach. J Embryol Exp Morphol 1964;12:563-573.

-9 Buznikov GA, Zvezdina ND, Makeeva RG: On the possible role of serotonin and other neurohormones in regulation of protein biosynthesis (experiments on sea urchin ova). Dokl Akad Nauk SSSR 1966;166:1252-1255.
0 Buznikov GA, et al: The role of neurohumours in early embryogenesis. 3. Pharmacological analysis of the role of neurohumours in cleavage divisions. J Embryol Exp Morphol 1970;23:549-569.

11 Buznikov GA, Shmukler YB, et al: From oocyte to neuron: do neurotransmitters function in the same way throughout development? Mol Cell Neurobiol 1996;16:532-555.

12 Buznikov G: Neurotransmitters in Embryogenesis. Chur, Academic Press, 1990.

13 Buznikov GA, Bezuglov VV: Polyenic acid 5-hydroxytryptamides and 3-hydroxytyramides as tools for studying of the pre-nervous biogenic monoamine functions. Ross Fiziol Zh 2000;86:1093-1108. 